\title{
Oxidative stress responses of juvenile tambaqui Colossoma macropomum after short-term anesthesia with benzocaine and MS-222
}

\author{
GIOVANNA R. STRINGHETTA ${ }^{1}$, LUIS A.L. BARBAS ${ }^{2}$, LUCAS C. MALTEZ ${ }^{1}$, LUÍS \\ A. SAMPAIO ${ }^{3}$, JOSÉ M. MONSERRAT ${ }^{4}$ and LUCIANO O. GARCIA ${ }^{1}$ \\ ${ }^{1}$ Instituto de Oceanografia, Universidade Federal do Rio Grande/FURG, Laboratório de \\ Aquacultura Continental, BR-392, Km 21, 96222-100 Rio Grande, RS, Brazil \\ ${ }^{2}$ Laboratório de Aquacultura de Espécies Tropicais, Instituto Federal de Educação, Ciência e \\ Tecnologia do Pará/IFPA, BR-316, Km 61, 68740-970 Castanhal, PA, Brazil \\ ${ }^{3}$ Instituto de Oceanografia, Estação Marinha de Aquacultura, Universidade Federal do Rio Grande/FURG, \\ Laboratório de Piscicultura Marinha e Estuarina, Rua do Hotel, 2, 96201-900 Rio Grande, RS, Brazil \\ ${ }^{4}$ Instituto de Ciências Biológicas, Universidade Federal do Rio Grande/FURG, Laboratório de \\ Fisiologia Animal Comparada, Avenida Itália, Km 8, 96201-900 Rio Grande, RS, Brazil \\ Manuscript received on November 25, 2016; accepted for publication on February 24, 2017
}

\begin{abstract}
The present study aimed to evaluate the effects of benzocaine and tricaine methanesulfonate on oxidative stress parameters of juvenile tambaqui tissues. Fish $(\mathrm{n}=80)$ were anesthetized with benzocaine $(100 \mathrm{mg}$ $\left.\mathrm{L}^{-1}\right)$ or tricaine $\left(240 \mathrm{mg} \mathrm{L}^{-1}\right)$ and two control groups were used (non-anesthetized fish and fish exposed to ethanol-only). After anesthetic induction 10 fish/anesthetic were euthanized after 3, 12 and 24 hours post-anesthesia and tissue samplings (gills, liver and brain) were performed. Samples were submitted to analyses of enzyme activity glutathione-S-transferase (GST), cellular lipid peroxidation (TBARS) and total antioxidant capacity (ACAP). ACAP increased in gills of benzocaine treatment after 12 hours. The liver showed a reduction in ACAP of tricaine treatment after 12 hours. Both anesthetic treatments showed an increase of ACAP at 24 hours compared to control group. The activity of the GST enzyme increased in the gills for treatments benzocaine and tricaine after 3 and 12 hours. Liver showed increased GST activity (benzocaine after 24 hours and tricaine after 3 and 24 hours). Lipid damage decreased in gills (both anesthetics) and brain (tricaine) after 24 hours. The results demonstrate that benzocaine and tricaine did not cause oxidative damage in juvenile tambaqui under the experimental conditions herein established.
\end{abstract}

Key words: Anesthetics, fish, GST, lipid peroxidation, total antioxidant capacity.

\section{INTRODUCTION}

The production of fish requires special attention during handling practices, such as biometrics, blood sampling and transport which are procedures

Correspondence to: Luciano de Oliveira Garcia

E-mail: garcia_log@hotmail.com likely to affect the growth and health of the animals. Handling is stressful to fish and the use of anesthetics is important under these circumstances to mitigate stress and reduce mortalities (Gomes 2001, Inoue et al. 2011, Sneddon 2012). Furthermore, the use of anesthetics can prevent deleterious effects of stress and stress-related diseases in fish (Weber III 2011). 
Many chemicals are used for fish anesthesia, among which the most commonly used are MS222 (tricaine methanesulfonate) and benzocaine; besides these, quinaldine, 2- phenoxyethanol, metomidate and Aqui- $\mathrm{S}^{\mathrm{TM}}$ are also frequently used (Gomes et al. 2001, Coyle et al. 2004, Sneddon 2012, Vera et al. 2013).

Tricaine, also known as MS-222 or tricaine methanesulfonate is a benzocaine isomer with a sulfonate radical, being a water- and lipid-soluble substance (Popovic et al. 2012). Preliminary data from our research group (L.A.L. Barbas et al., personal communication) indicated that the effective anesthetic concentration of tricaine for juvenile tambaqui without causing mortality is 240 $\mathrm{mg} \mathrm{L^{-1 }}$.

Another anesthetic, benzocaine (ethyl p-aminobenzoate), is the most commonly used fish anesthetic in Brazil, mainly because it is an easy-to-purchase, safe-to-users and cost-effective product (Gimbo et al. 2008). Many studies have been conducted on the anesthetic potential of benzocaine for different species, such as the crucian carp, Carassius carassius (Heo and Shin 2010), matrinxã, Brycon cephalus (Inoue et al. 2004), pompano, Trachinotus marginatus (Okamoto et al. 2009) and fat snook, Centropomus parallelus (Souza et al. 2012). Gomes et al. (2001) evaluated the anesthetic efficacy of benzocaine for tambaqui, and the concentration of $100 \mathrm{mg}$ $\mathrm{L}^{-1}$ was recommended for this species as a safe concentration without causing mortality.

Although anesthesia is capable of mitigating biochemical and physiological disorders in fish caused by handling, the anesthetic per se may induce changes in biochemical profile that may lead to oxidative stress (Velisek et al. 2011). Therefore, these physiological changes may trigger an oxidative stress scenario (Halliwell and Gutteridge 1999), which is characterized by an imbalance between the production of pro oxidants and the antioxidant defense cells.
These changes may occur due to hypoxia caused by impaired ventilation when fish are anesthetized or, otherwise, due to re-oxygenation that may lead to a hyperoxic condition at the moment fish are returned to normal oxygen-saturated water during recovery (Azambuja et al. 2011). The pro oxidants or Reactive Oxygen Species (ROS) are formed via oxygen reduction in tissues (Belló et al. 2000) and are over generated in organisms exposed to xenobiotics (Tew and Ronai 1999, Monserrat et al. 2007) or submitted to stress conditions. ROS are responsible for damage to cellular proteins, lipids, nucleic acids, among other structures, leading to permanent damage in tissues and organs (Storey 1996, Lushchak et al. 2005, Fogaça and Sant'Ana 2009) in different animals.

Tambaqui, Colossoma macropomum (Cuvier 1816) is an omnivorous species indigenous to the basins of Amazon and Orinoco rivers (AraujoLima and Goulding 1997). In natural environment this species can reach up to one meter in length and $30 \mathrm{~kg}$ in weight (Saint-Paul 1986). It is well adapted to captive conditions, easily accepting artificial diets, presents good growth rates and feed conversion (Inoue et al. 2011).

Therefore, our study aimed to evaluate the effects of anesthesia with bezocaine and MS-222 on oxidative stress responses in gills, liver and brain of juvenile tambaqui after short-term anesthesia.

\section{MATERIALS AND METHODS}

Fish were purchased from a commercial fish farm (Rio Preto da Eva, Amazon, northern Brazil), shipped by air and maintained under acclimation at the Continental Aquaculture Laboratory of the Universidade Federal do Rio Grande - FURG, in southern Brazil, for 30 days, under controlled conditions, in five tanks of $250 \mathrm{~L}$ capacity, filled with freshwater, arranged in a recirculation system. All acclimation and experimental conditions were 
accordingly to the FURG Ethics Committee on Animal Use permission $\mathrm{n}^{\circ} \mathrm{P} 021 / 2015$.

Water parameters (mean \pm SEM) were maintained as follows: Temperature (T): 27.3 $\pm 0.14{ }^{\circ} \mathrm{C}$ and Dissolved Oxygen (DO): $6.7 \pm$ $0.06 \mathrm{mg} \mathrm{L}^{-1}$ (oxygen meter YSI DO200A Yellow Springs Instruments). The $\mathrm{pH}(7.5 \pm 0.03)$ was also measured daily using a $\mathrm{pH}$ meter (Hanna Instruments HI 8424). Total ammonia nitrogen (TAN) $\left(0.8 \pm 0.28 \mathrm{mg} \mathrm{L}^{-1}\right)$ was determined according to Eaton et al. (2005), and nitrite (0.03 $\left.\pm 0.01 \mathrm{mg} \mathrm{L}^{-1}\right)$ and total alkalinity $(70.0 \pm 0.1 \mathrm{mg}$ $\mathrm{CaCO}_{3} \mathrm{~L}^{-1}$ ) were evaluated in accordance to Boyd (1998). A 12 L/12D photoperiod was fixed. During experimental period values of temperature, DO, alkalinity and $\mathrm{pH}$ were maintained at the same conditions of those from the acclimation tanks; TAN and nitrite were $0.04 \pm 0.01 \mathrm{mg} \mathrm{L}^{-1}$ and $0.0 \mathrm{mg} \mathrm{L}^{-1}$, respectively. During acclimation fish were fed twice a day (09:00 and 16:00 h) at 2\% of biomass with a $28 \%$ crude protein commercial feed. All animals were starved for $24 \mathrm{~h}$ prior to the tests. Feces and feed residues were siphoned from the bottom of the tanks daily and the water was replenished under the same conditions as in the acclimation tanks $(20 \%$ of the system's total volume of water).

Two anesthetics were used in the experiment: tricainemethanesulphonate (Sigma Chemical E10521 - St Louis, MO, USA) and benzocaine (Sigma Chemical E1501 - St Louis, MO, USA). Tricaine was dissolved directly in the anesthesia tank water and buffered with $\mathrm{NaHCO}_{3}$ at a $1: 1$ ratio to achieve a neutral $\mathrm{pH}$ (7.0). Benzocaine is insoluble in water and therefore needs to be pre-diluted in ethanol (1:10) (Zahl et al. 2011) to provide a stock solution before being added to the anesthesia water.

A total of 80 tambaqui juveniles $(45.18 \pm 1.04$ g; $14.91 \pm 0.12 \mathrm{~cm}$ ) were used. A group of $30 \mathrm{fish}$ was anesthetized with a benzocaine concentration of $100 \mathrm{mg} \mathrm{L}^{-1}$, as recommended for this species by
Gomes et al. (2001). Another group of 30 fish was anesthetized with a concentration of $240 \mathrm{mg} \mathrm{L}^{-1}$ of MS-222. In both trials, fish were anesthetized individually in $30 \mathrm{~L}$ aquaria containing $10 \mathrm{~L}$ of the acclimation tank water. Each fish was kept in the aquarium with anesthetic until deep anesthesia was observed, i.e., total loss of equilibrium with minimum opercular beating (adapted from Park et al. 2008). The anesthetic concentrations used were sufficient to promote fast and short-term anesthesia ( $<3 \mathrm{~min}$ ) as recommended by Iwama and Ackerman (1994) for quick interventions on fish, i.e., tagging, weighing or sorting. Thereafter, specimens were allowed to recover in $40 \mathrm{~L}$ tanks, in groups of 10 fish each. Water quality in the recovery tanks had the same conditions as in the acclimation tanks but without anesthetics. Fish were maintained in the recovery tanks until tissue samplings were carried out.

Three sampling points were established during recovery: 3, 12 and $24 \mathrm{~h}$ post-anesthesia (PA). For each treatment (anesthetic) and sampling time, a group of 10 fish was used. Also a group of 10 nonanesthetized fish was used as a control group. To verify if the ethanol used to dissolve benzocaine could cause any biochemical alteration in the fish tissues, another group was kept for 3 minutes in a 30 $\mathrm{L}$ aquarium containing $10 \mathrm{~L}$ of the acclimation tank water with the same volume of ethanol used for the benzocaine dilution. The control and ethanol group also went through a recovery simulation procedure, and only then the tissues were collected in the same sample points of the animals anesthetized.

Fish were randomly captured with a dip net and euthanized with a blow to the head, and gills, liver and brain were collected. The tissues were maintained in an ultra-freezer $\left(-80{ }^{\circ} \mathrm{C}\right)$ and then homogenized $(1: 5, \mathrm{w} / \mathrm{v})$ in buffer containing 100 mMTris- $\mathrm{HCl}, 2 \mathrm{mMEDTA}$ and $5 \mathrm{mM} \mathrm{MgCl} \mathrm{m}_{2} \cdot 6 \mathrm{H}_{2} \mathrm{O}$, with $\mathrm{pH}$ ajusted in 7.75. The supernatants resulting from the centrifugation of the homogenates $\left(10,000 \mathrm{xg}, 20\right.$ minutes, $\left.4^{\circ} \mathrm{C}\right)$ were used for all 
analyses. Total protein content of supernatants was determined through Biuret method (Kit Proteínas Totais Doles ${ }^{\circledR}$ ).

Thereafter, samples of gills and liver were diluted and homogenized with buffer solution to $2.0 \mathrm{mg}$ protein $\mathrm{mL}^{-1}$ (gills and liver) or to $0.5 \mathrm{mg}$ protein $\mathrm{mL}^{-1}$ (brain) for posterior analysis of Total Antioxidant Capacity Against Peroxyl Radicals (ACAP) determined according to the method described by Amado et al. (2009). Briefly, it was employed a peroxyl radical generator, 2,2'-azobis (2 methylpropionamidine) dihydrochloride (ABAP) that is thermolabile. Peroxyl radicals reacted with $2^{\prime}, 7^{\prime}$-dichlorofluorescin diacetate $\left(\mathrm{H}_{2} \mathrm{DCF}-\mathrm{DA}\right)$, that generated a fluorochrome. The fluorescence was determined through a microplate reader (Victor 2, Perkin Elmer) at $37{ }^{\circ} \mathrm{C}$ (excitation: $485 \mathrm{~nm}$; emission: $520 \mathrm{~nm}$ ) with readings every 5 minutes, for 30 minutes in sample aliquots where it was added ABAP and other aliquots of the same samples that it was added distilled water. The results were expressed as a relative area (the difference between the area with and without ABAP divided by the area without ABAP). For interpretation purposes, a higher relative area means a lower antioxidant competence and vice-versa.

The lipid peroxidation (LPO) content of all tissues was measured using the methodology described by Oakes and Van Der Kraak (2003). The concentration of thiobarbituric acid reactive substances (TBARS) was measured adding to $30 \mu \mathrm{L}$ (brain) and $15 \mu \mathrm{L}$ (liver or gill) of sample homogenate, $20 \mu \mathrm{L}$ BHT solution $(67 \mu \mathrm{M}), 150$ $\mu \mathrm{L} 20 \%$ acetic acid solution, $150 \mu \mathrm{L}$ of $0.8 \%$ thiobarbituric acid solution, $50 \mu \mathrm{L}$ Milli-Q $\mathrm{H}_{2} \mathrm{O}$, and $20 \mu \mathrm{L}$ SDS at $8.1 \%$. The mixture was heated at $95{ }^{\circ} \mathrm{C}$ for 30 minutes. Thereafter, $100 \mu \mathrm{L}$ Milli-Q $\mathrm{H}_{2} \mathrm{O}$ and $500 \mu \mathrm{L}$-butanol were added to the final solution. After centrifugation, the remaining supernatant $\left(3,000 \mathrm{x} g, 10\right.$ minutes, $\left.15^{\circ} \mathrm{C}\right)$ was used to determine the fluorescence (excitation: $520 \mathrm{~nm}$; emission: $580 \mathrm{~nm}$ ) and the results were expressed as nmol TMP mg protein ${ }^{-1}$, where TMP stands for tetramethoxypropane employed as standard.

For the determination of GST activity, the methodology described by Habig et al. (1974) was followed. A potassium phosphate buffer $\left(\mathrm{KH}_{2} \mathrm{PO}_{4}-\right.$ $0.05 \mathrm{M} ; \mathrm{K}_{2} \mathrm{HPO}_{4}-0.05 \mathrm{M}$; and Milli-Q $\mathrm{H}_{2} \mathrm{O} ; \mathrm{pH}=$ 7.0) was used as reaction buffer (previously heated to $25^{\circ} \mathrm{C}$ using a water bath) for the conjugation of 1-chloro-2,4-dinitrobenzene (CDNB) with reduced glutathione (GSH) both at a final concentration of 1 mM.CDNB, GSH and $10 \mu \mathrm{L}$ of sample homogenate were added to a transparent 96 well microplate and the absorbance increments were read at $340 \mathrm{~nm}$ using a microplate reader (Victor 2, Perkin Elmer). The results were expressed as nmol of CNDB-GSH conjugate mg protein ${ }^{-1} \mathrm{~min}^{-1}$.

The experimental design was completely randomized with 4 treatments: two control groups (control and alcohol), with 10 fish each, and two other treatments (benzocaine and MS-222) in which three sampling points were established (3, 12 and 24 hours after anesthesia). Each anesthetic treatment consisted of 10 repetitions (each fish was considered a replicate) in a total of 80 animals. No mortalities were observed throughout the trial period.

All data were expressed as means \pm standard deviation (SD). To verify the normality and homogeneity of variances, data were submitted to Kolmogorov-Smirnov and Levene tests, respectively. When assumptions were not satisfied, the necessary mathematical transformations were performed. Thereafter, data were submitted to a Two-Way ANOVA (with anesthetic and sampling time used as factors) followed by Tukey test. When ANOVA assumptions were not met, even after transformation, non-parametric KruskallWallis test was performed followed by MannWhitney multiple comparisons test. Data from both control groups were compared by $\mathrm{T}$ Test and no significant differences were attained. 
Therefore, only data from non-anesthetized fish were used. All analyses were performed with a significance level of $5 \%(\mathrm{p}<0.05)$ in all cases.

\section{RESULTS}

\section{TOTAL ANTIOXIDANT CAPACITY - ACAP}

A significant increase $(\mathrm{p}<0.05)$ was observed in total antioxidant capacity in gills of fish anesthetized with benzocaine compared to those exposed to tricaine and control group after $12 \mathrm{~h} \mathrm{PA}$. Moreover, a higher $(p<0.05)$ total antioxidant capacity was observed in gills after $12 \mathrm{~h}$ compared to $24 \mathrm{~h} \mathrm{PA}$ in fish exposed to benzocaine (Figure 1a). Irrespective of tissue considered, no differences ( $p>0.05$ ) were observed over time in fish exposed to tricaine.

In relation to the liver, no significant differences ( $p>0.05$ ) were observed among treatments or over time. Meanwhile, fish anesthetized with tricaine showed a significant decrease $(p<0.05)$ of the antioxidant capacity compared to control after 12 h PA (Figure 1b).

Brain showed no significant differences $(p>0.05)$ between treatments or over time. However, fish anesthetized with benzocaine and tricaine showed a greater antioxidant capacity after 24 h PA compared to control group (Figure 1c).

\section{GLUTATHIONE S-TRANSFERASE - GST}

The GST activity in gills was indistinguishable between treatments $(p>0.05)$ and a significant increase was observed after 3 and $12 \mathrm{~h}$ PA in gills of animals anesthetized with benzocaine and tricaine compared to control (Figure 2a).

Only $24 \mathrm{~h} \mathrm{PA}$, liver of fish exposed to benzocaine showed a significant increment $(p<0.05)$ in GST activity compared to control. Hepatic GST activity increased for tricaine treatment compared to control group after 3 and $24 \mathrm{~h} \mathrm{PA}$, being the latter also significantly higher than the activity observed after 12 h PA ( $<<0.05$; Figure 2b). GST activity in brain of tambaqui was more elevated for benzocaine treatment after 12 and $24 \mathrm{~h}$ compared to $3 \mathrm{~h} \mathrm{PA}(\mathrm{p}<0.05$; Figure $2 \mathrm{c})$. Nevertheless, no differences $(p>0.05)$ were observed between GST activity in brain of control group when compared to any of the treatments (Figure 2c).

LIPID PEROXIDATION - TBARS

A significant reduction $(\mathrm{p}<0.05)$ in lipid peroxidation levels of gills was verified after 24 $\mathrm{h}$ PA in fish anesthetized with benzocaine and tricaine compared to control group (Figure 3a). Tricaine treatment elicited a significant decline $(p<0.05)$ in lipid peroxidation levels of liver after $24 \mathrm{~h}$ PA compared to LPO levels in $3 \mathrm{~h}$ PA (Figure $3 b)$. Nevertheless, no differences $(p>0.05)$ were observed between hepatic LPO levels of control group compared to any of the treatments (Figure $3 b)$.

Brain of fish anesthetized with tricaine showed a significant decrease $(p<0.05)$ in LPO levels $24 \mathrm{~h}$ PA compared to control, whereas brain of fish exposed to benzocaine showed a significant intensification $(\mathrm{p}<0.05)$ in LPO levels after $12 \mathrm{~h}$ compared to the levels observed $3 \mathrm{~h}$ PA (Figure $3 \mathrm{c}$ ).

\section{DISCUSSION}

Oxidative stress is triggered by an imbalance between the concentration of prooxidants and antioxidants in an organism (Halliwell and Gutteridge 1999). Several factors can favor this condition, as in the case of exposure to pollutants and xenobiotics, including anesthetics (Velisek et al. 2011, Guptha et al. 2016, Lushchak 2016).

GST enzymes promote detoxification of tissues by catalyzing the conjugation of reduced glutathione $(\mathrm{GSH})$ to nucleophilic molecules (Storey 1996). Enhanced GST activity was observed in gills and liver of fish exposed to either anesthetics, which can be interpreted as an attempt to detoxify the drugs in these tissues. An increment 

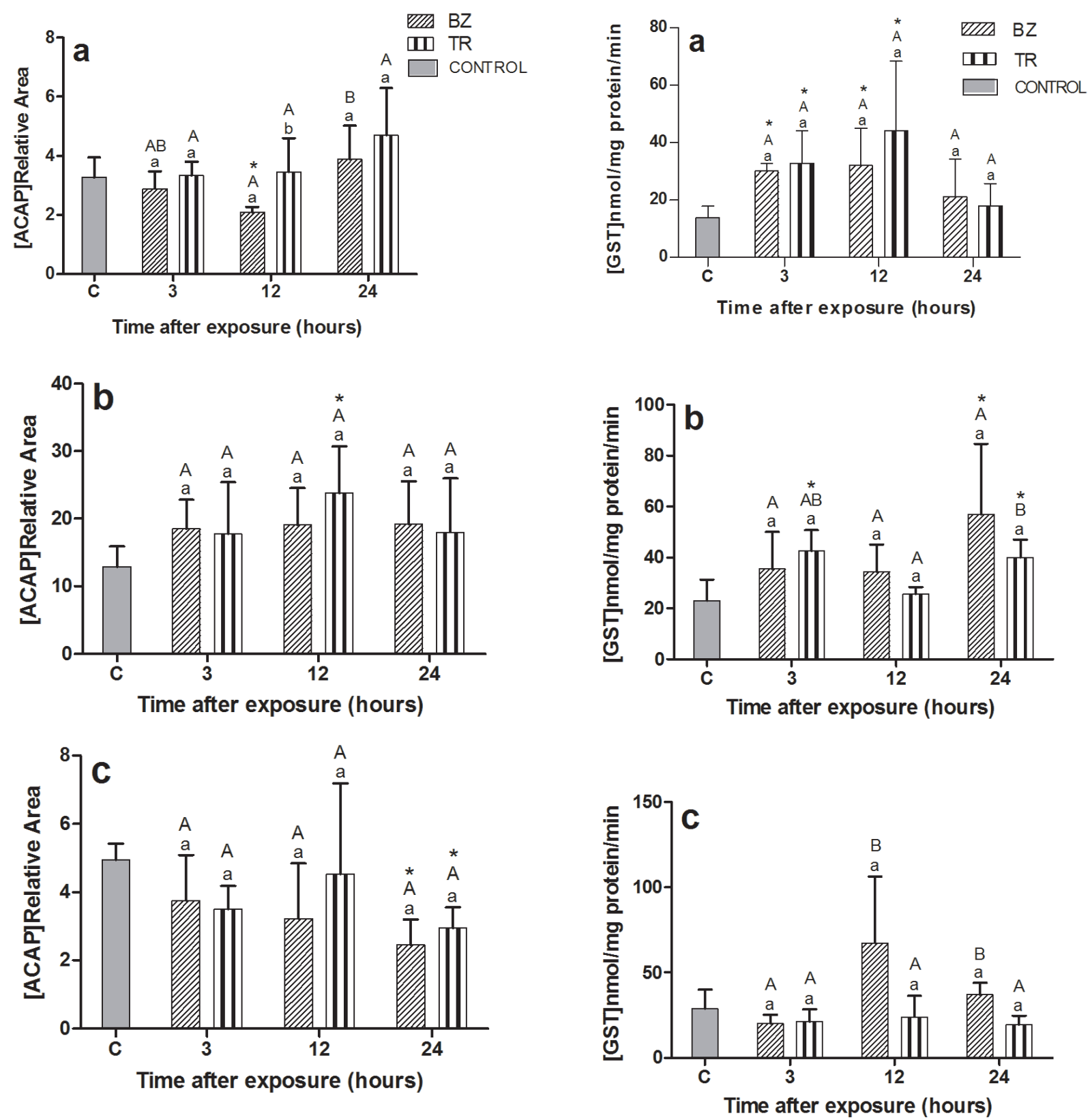

Figure 1 - Total antioxidant capacity (ACAP) of gills (a), liver (b) and brain (c) of juvenile tambaqui, Colossoma macropomum anesthetized with benzocaine or tricaine. Values are expressed as means \pm SD. Different lowercase letters indicate significant differences between treatments (anesthetics) within sampling time; different capital letters indicate significant differences within treatment over time; asterisk indicates significantly different from control $(C)(n=10, p<0.05)$.

Figure 2 - Activity of the enzyme glutathione S-transferase (GST) of gills (a), liver (b) and brain (c) of juvenile tambaqui, Colossoma macropomum anesthetized with benzocaine or tricaine. Values are expressed as means \pm SD. Different lowercase letters indicate significant differences between treatments (anesthetics) within sampling time; different capital letters indicate significant differences within treatment over time; asterisk indicates significantly different from control (C) $(\mathrm{n}=10, \mathrm{p}<0.05)$. 

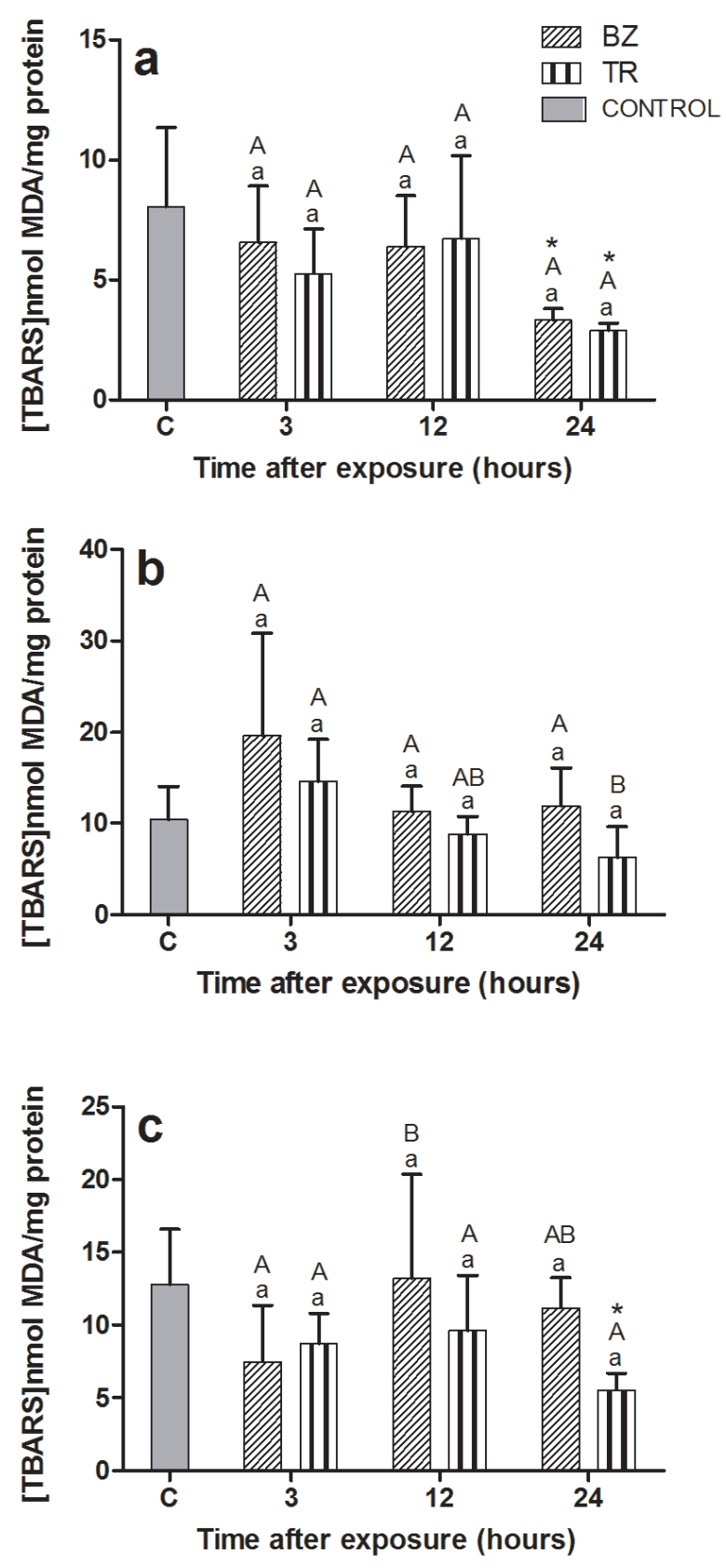

Figure 3 - Levels of lipid peroxidation (TBARS) of gills (a), liver (b) and brain (c) of juvenile tambaqui, Colossoma macropomum anesthetized with benzocaine or tricaine. Values are expressed as means \pm SD. Different lowercase letters indicate significant differences between treatments (anesthetics) within sampling time; different capital letters indicate significant differences within treatment over time; asterisk indicates significantly different from control (C) $(\mathrm{n}=$ $10, \mathrm{p}<0.05)$. in GST activity was also described by Salbego et al. (2015) for silver catfish, Rhamdia quelen submitted to transportation with methanolic extract of Condalia Buxifolia used as a sedative added to the water. GST activity increased in liver of Rhamdia quelen submitted to anesthesia with essential oil of Aloysia triphylla (135 and $180 \mathrm{mg} \mathrm{L}^{-1}$ ), which was also reported by Gressler et al. (2014). Yet, the same authors detected a decreased GST activity in the liver of this species when individuals were submitted to anesthesia with tricaine (150 and 300 $\left.\mathrm{mg} \mathrm{L}^{-1}\right)$.

Tambaqui is a species that commonly tolerates little dissolved oxygen in the water and is capable of providing an emergency respiration system when necessary (Saint-Paul 1986). However, species that usually go through a period of time with low oxygen consumption tend to readjust their antioxidant activity to prevent the damage caused by the ROS generated after re-oxygenation (Azambuja et al. 2011). As anesthetics may induce a state of hypoxia in fish though impairment of opercular beat (Zahl et al. 2012), the increment of GST activity in gills of fish 3 and $12 \mathrm{~h}$ PA was probably an attempt to try to detoxify this organ from endogenous products of lipid peroxidation (Storey 1996, Lushchak et al. 2005). After $24 \mathrm{~h} \mathrm{PA}$, the GST activity returned to similar levels of those from control group, showing that the anesthetics were no longer instigating late antioxidant activity or else had been already cleared from the tissue. Furthermore, in the gills, levels of LPO also decreased at 24h PA, reinforcing the scenario of a tissue with less ROS activity. Both tricaine and benzocaine showed increases in hepatic GTS activity after 3 and $24 \mathrm{~h}$ PA compared to control, however, this activity did not differ from control after $12 \mathrm{~h}$. This rebounded enzymatic response (24 h PA) in liver may occur because this is an organ with great detoxifying potential, and this detoxifying activity may persist in this organ for a high period of time, even a few days (Tkachenko et al. 2014). 
Although enzymatic activities are a reliable indicator of oxidative stress generation, each organ, tissue, and organism may respond differently under a pro-oxidant condition, gathering enzymatic and non-enzymatic responses against the ROS generated (Amado et al. 2009). Therefore, total antioxidant capacity was evaluated, and an increase of ACAP in gills of fish after $12 \mathrm{~h}$ PA with benzocaine was observed. Total antioxidant capacity also incorporates enzymatic activities, including GST. Increasing activity of GST was observed in fish anesthetized with benzocaine and tricaine until $12 \mathrm{~h}$ PA. These results allow us to state that fish anesthetized with these two anesthetic substances do not exhibit prolonged changes in antioxidant activity.

Anesthetics can inhibit the propagation of action potentials in fish cells inducing an interruption of neural signal transmission, thus the brain loses nociception (Zahl et al. 2012). Despite this knowledge that anesthetics have indirect influence over brain, little is known about their direct effects and the general antioxidant activity in fish brain. Consequently the increase of the total antioxidant capacity in brain of tambaqui after $24 \mathrm{~h}$ PA of the present study remains uncertain, and will require further studies.

The gills of the fish anesthetized with benzocaine and tricaine showed decreased LPO 24 h PA. As explained by Storey 1996 and Lushchak et al. 2005, it was likely a result of increased GST activity, which between 3 and $12 \mathrm{~h}$ PA enhanced the detoxification process, leading to decreased LPO levels in that organ. It is also plausible that the anesthetic had been already cleared from the tissue after 24 hours, which could also explain the decreased GST activity by that time.

Lipid peroxidation levels were unchanged in liver after exposure to benzocaine, however LPO levels in fish anesthetized with tricaine varied over time, and lipid peroxidation decreased at 24 h compared to $3 \mathrm{~h}$ PA. Again, as aforementioned, it could be a result of the high detoxifying capacity of the liver (Tkachenko et al. 2014), which along with the activity of the GST enzyme, was capable to reduce LPO over time after the administration of the anesthetic. Differently from our findings, Gressler et al. (2014) observed decreased lipid peroxidation in liver of Rhamdia quelen during recovery, after being anesthetized with tricaine at $300 \mathrm{mg} \mathrm{L}^{-1}$.

The decreased LPO levels in brain of fish anesthetized with tricaine $24 \mathrm{~h}$ PA paralleled elevations in total antioxidant capacity observed in this organ at the same time. Total antioxidant capacity and LPO levels are closely related, because ACAP is related to general antioxidant competence (enzymatic and non-enzymatic) and the level of lipid peroxidation is an indicator of the balance state between ROS and ACAP (Machado et al. 2013). In general, antioxidant responses after short-term anesthesia observed in the present study seemed to have been sufficient to protect tissues against lipid peroxidation. Similar or lower LPO levels were observed in all tissues over time compared to control group, demonstrating that the use of both anesthetics did not promote oxidative stress up to $24 \mathrm{~h}$ in recovery. The relatively limited number of sampling points established herein may have overlooked the precise response of fish tissues as affected by either anesthetics, hence, additional studies should be conducted in order to add further knowledge in this regard.

Velisek et al. (2011) compared the effects of four anesthetics (MS-222, clove oil, 2-phenoxyethanol e Propiscin) on oxidative stress biomarkers in rainbow trout, Oncorhynchus mykiss (107.8 g), from which brain and liver exposed to MS-222 (24 h PA) showed the highest levels of LPO compared to control group, suggesting that Propiscin may be better than MS-222 because it causes less oxidative damage. Zeppenfeld et al. (2014) evaluated the LPO level in the liver of Rhamdia quelen after 6 hours of transportation with two distinct concentrations 
of Aloysia triphylla essential oil at 27 and $36 \mathrm{mg}$ $\mathrm{L}^{-1}$, and observed lower lipid peroxidation levels in animals exposed to these concentrations when compared to control group.

In conclusion, short-term anesthesia with benzocaine $\left(100 \mathrm{mg} \mathrm{L}^{-1}\right)$ and tricaine $\left(240 \mathrm{mg} \mathrm{L}^{-1}\right)$ did not cause oxidative damage in gills, liver and brain of juvenile tambaqui during recovery for up to $24 \mathrm{~h}$. Moreover, it seems that antioxidant responses post-anesthesia were sufficient to prevent lipid peroxidation of tissues. We can also imply that short-term anesthesia with either products at the concentrations tested in the present study can be safely used for handling purposes of juvenile tambaqui.

\section{REFERENCES}

AMADO LL, GARCIA ML, RAMOS PB, FREITAS RF, ZAFALON B, FERREIRA JRL, YUNES JS AND MONSERRAT JM. 2009. A method to measure total antioxidant capacity against peroxyl radicals in aquatic organisms: Application to evaluate microcystins toxicity. Sci Total Environ 40: 2115-2123.

AZAMBUJA CR, MATTIAZZI J, RIFFEL APK, FINAMOR IA, GARCIA LO, HELDWEIN CG, HEIZMANN BM, BALDISSEROTO B, PAVANATO MA AND LLESUY SF. 2011. Effect of the essencial oil of Lippia alba on oxidative stress parameters in silver catfish (Rhamdia quelen) subjected to transport. Aquaculture 319: 156-161.

ARAUJO-LIMA C AND GOULDING M. 1997. So fruitful a fish. Ecology, conservation and aquaculture of the Amazon's tambaqui. New York: Columbia University Press, $191 \mathrm{p}$.

BELLÓ ARR, FORTES E, BELLÓ-KLEIN A, BELLÓ AA, LLESUY SF, ROBALDO RB AND BIANCHINI A. 2000. Lipid peroxidation induced by Clinostomum detruncatum in muscle of the freshwater fish Rhamdia quelen. Dis Aquat Org 42: 233-236.

BOYD CE. 1998. Water quality management for pond fish culture: research and development. Int Cent Aquac Aquatic Environ 43: 1-37.

COYLE SD, DURBOROW RM AND TIDWELL JH. 2004. Anesthetics in aquaculture. Southern Regional Aquaculture Center (SRAC). Publication 3900.

EATON AD, CLESCERI LS, RICE EW AND GREENBERG AE. 2005. Standard methods for the examination of water and wastewater. $21^{\text {st }}$ ed., Springfield: American Public Health Association.
FOGAÇA FHS AND SANT'ANA LS. 2009. Oxidação lipídica em peixes: mecanismo de ação e prevenção (artigo de revisão). Arch Vet Sci 14: 117-127.

GIMBO RY, SAITA MV, GONÇALVES AFN AND TAKAHASHI LS. 2008. Diferentes concentrações de benzocaína na indução anestésica do lambari-do-raboamarelo (Astyanax altiparanae). Rev Bras Saúde Prod Anim 9: 350-357.

GOMES LC, CHIPPARI-GOMES AR, LOPES NP, ROUBACH R AND ARAUJO-LIMA CARM. 2001. Efficacy of benzocaine as an anesthetic in juvenile tambaqui Colossoma macropomum. J Aquac Soc 32: 426431.

GRESSLER LT ET AL. 2014. Silver catfish Rhamdia quelen immersion anaesthesia with essential oil Aloysia triphylla (L'Herit) Britton or tricaine methanesulfonate: effect on stress response and antioxidant status. Aquac Res 45: 1061-1072.

GUPTHA JS, RENUKA M, SUNEETHA Y AND REDDY MS. 2016. Evaluation of antioxidant defence system during xenobiotic induced oxidative stress in freshwater fish Oreochromis mossambicus. Int J Fish Aquat Stud 4: 379-385.

HABIG WH, PABTS MJ AND JACOBI WB. 1974. GlutationaS-Transferase. The first enzymatic step in mercapturic acid formation. J Biol Chem 249: 7130-7439.

HALLIWELL B AND GUTTERIDGE JMC. 1999. Free radicals in biology and medicine. $3^{\text {rd }}$ ed., Oxford University Press.

HEO GJ AND SHIN G. 2010. Efficacy of benzocaine as an anaesthetic for Crucian carp (Carassius carassius) (short communication). Vet Anaest Analg 37: 132-135.

INOUE LAKA, BOIJINK CL, RIBEIRO PT, SILVA AMD AND AFFONSO EG. 2011. Avaliação de respostas metabólicas do tambaqui exposto ao eugenol em banhos anestésicos. Acta Amazon 41: 327-332.

INOUE LAKA, HACKBARTH A AND MORAES G. 2004. Avaliação dos anestésicos 2-phenoxyethanol e benzocaína no manejo de matrinxã Brycon cephalus (Günther, 1869). Biodiv Pamp 2: 10-15.

IWAMA GK AND ACKERMAN P. 1994. Anesthetics. Biochemistry and Molecular Biology of Fishes, Hochachka PW and Mommsen TP(Eds), Amsterdam: Elsevier Science 3: $1-15$.

LUSHCHAK VI. 2016. Contaminant-induced oxidative stress in fish: a mechanistic approach. Fish Physiol Biochem 42: 711-747.

LUSHCHAK VI, BAGNYUKOVA TV, HUSAK VV, LUZHNA LI, LUSHCHAK OV AND STOREY KB. 2005. Hyperoxia results in transient oxidative stress and an adaptive response by antioxidant enzymes in goldfish tissues. Int J Biochem Cell Bio 37: 1670-1680. 
MACHADO AAS, HOFF MLM, KLEIN RD, CARDOZO JG, GIACOMIM MM, PINHO GLL AND BIANCHINI A. 2013. Biomarkers of waterborne copper exposure in the guppy Poecilia vivipara acclimated to salt water. Aquat Toxicol 138-139: 60-69.

MONSERRAT JM, MARTINEZ PE, GERACITANO LA, AMADO LL, MARTINS CMG, PINHO GLL, CHAVES IS, FERREIRA-CRAVO M, LIMA JV AND BIANCHINI A. 2007. Pollution biomarkers in estuarine animals: critical review and new perspectives. Comp Biochem Physiol C 146: $221-234$

OAKES KD AND VAN DER KRAAK GJ. 2003. Utility of the TBARS assay in detecting oxidative stress in white sucker (Catostomus commersoni) populations. Aquat Toxicol 63: 447-463.

OKAMOTO MH, TESSER MB, LOUZADA LR, SANTOS RA AND SAMPAIO LA. 2009. Benzocaína e eugenol como anestésicos para juvenis do pampo Trachinotus marginatus. Cienc Rur 39: 866-870.

PARK MO, HUR WJ, IM SY, SEOL DW, LEE J AND PARK IS. 2008. Anaesthetic efficacy and physiological responses to clove oil-anaesthetized kelp grouper Epinephelus bruneus. Aquac Res 39: 877-884.

POPOVIC NT, STRUNJAK-PEROVIC I, COZ-RAKOVAC R, BARISIC J, JADAN M, BERAKOVIC AP AND KLOBUCAR RS. 2012. Tricaine methane-sulfonate (MS222). J Appl Ichthyol 28: 553-564.

SAINT-PAUL U. 1986. Potential for aquaculture of South American freshwater fishes: A review. Aquaculture 54: 205-240.

SALBEGO J ET AL. 2015. Methanolic extract of Condalia buxifolia added to transport water alters biochemical parameters of the silver catfish Rhamdia quelen. Aquaculture 437: 46-50.

SNEDDON LU. 2012. Clinical anesthesia and analgesia in fish. J Exot Pet Med 21: 32-43.

SOUZA RAR, CARVALHO CVA, NUNES FF, SCOPEL BR, GUARIZI JD AND TSUZUKI MY. 2012. Efeito comparativo da benzocaína, mentol e eugenol como anestésicos para juvenis de robalo peva. Bol Inst Pesca 38: 247-255.

STOREY KB. 1996. Oxidative stress: animal adaptations in nature. Braz J Medic Biologic Res 29: 1715-1733.

TEW KD AND RONAI Z. 1999. GST function in drug and stress response. Drug Resist Upd 2: 143-147.

TKACHENKO H, KURHALUK N, GRUDNIEWSKA J AND ANDRIICHUK A. 2014. Tissue-specific responses of oxidative stress biomarkers and antioxidant defenses in rainbow trout Oncorhynchus mykiss during a vaccination against furunculosis. Fish Physiol Biochem 40: 12891300.

VELISEK J, STARA A, LI Z-H, SILOVSKA S AND TUREK J. 2011. Comparison of the effects of four anesthetics on blood biochemical profiles and oxidative stress biomarkers in rainbow trout. Aquaculture 310: 369-275.

VERA LM, MONTOYA A AND SÁNCHEZ-VÁZQUEZ FJ. 2013. Effectiveness of the anaesthetic MS-222 in gilthead seabream, Sparus aurata: Effect of feeding time and daynight variations in plasma MS-222 concentration and GST activity. Physiol \& Behav 110-111: 51-57.

WEBER III ES. 2011 Fish analgesia: pain, stress, fear aversion, or nociception? Veterinary Clinics of North America: Exot Anim Pract J 14: 21-32.

ZAHL IH, KIESSLING A, SAMUELSEN OB AND HANSEN MK. 2011. Anaesthesia of atlantic halibut (Hippoglossus hippoglossus) - Effect of pre-anaesthetic sedation, and importance of body weight and water temperature. Aquac Res 42: 1235-1245.

ZAHL IH, SAMUELSEN O AND KIESSLLING A. 2012. Anaesthesia of farmed fish: implications for welfare. Fish Physiol Biochem 38: 201-218.

ZEPPENFELD CC ET AL. 2014. Physiological and biochemical responses of silver catfish, Rhamdia quelen, after transport in water with essential oil of Aloysia triphylla (L'Herit) Britton. Aquaculture 418-419: 101-107. 